\title{
The Reflections of New Elementary Education Curriculum on Media
}

\author{
İsmail GÜVEN*
}

Canay DEMIRHAN IŞCAN ${ }^{* *}$

\begin{abstract}
The Elementary Education curriculum were revised in 2004 in Turkey. There have been appeared many news in various newspapers with different tendencies such as conservative and liberal and so forth. The media has played its role to introduce new curricula by its own perceptions or the perceptions of formal authorities. This study addresses on the informative part of this reform: the attempts to introduce into public through media especially the newspapers. The main findings of this study are based on the news and discussions that were appeared on the media besides documentary analysis. It is found that the changes of new elementary education programs were not clearly conceptualized and there were serious lack of communication and information in media. The Turkish daily newspapers, especially, dealt with the popular sides and printed the reportages by staff from Ministry of National Education in spite of detailed study and researches on programs. They paid attention only the slogans of program developers. Just few of them only elicited the results of studies and opinions of educational experts.
\end{abstract}

Key Words: Media, elementary education, programme

\footnotetext{
* Assoc.Prof.Dr. Ankara University, Faculty of Educational Sciences, Department of Elementary Education

${ }^{* *}$ Research Asist. Ankara University, Faculty of Educational Sciences, Department of Elementary Education
} 


\section{SUMMARY}

The Elementary Education curriculum were revised in 2004 in Turkey. A large-scale educational reform has been implementing since 2005 in elementary education in country level. This reform aimed at major changes in the elementary education programs in subjects' basis and has been described as "constructivist education reform". The existing subjects such as social studies, science, mathematics and Turkish are addressing social and technical competencies and all these are expected to incorporate into curriculum in terms of reforms' framework. The interests in this program and its educational competencies and activities have been closely watched by media as well. There have been appeared many news in various newspapers with different tendencies such as conservative and liberal and so forth. The media has played its role to introduce new curricula by its own perceptions or the perceptions of formal authorities. This study addresses on the informative part of this reform: the attempts to introduce into public through media especially the newspapers. The main findings of this study are based on the news and discussions that were appeared on the media besides documentary analysis. It is found that the changes of new elementary education programs were not clearly conceptualized and there were serious lack of communication and information in media. The Turkish daily newspapers, especially, dealt with the popular sides and printed the reportages by staff from Ministry of National Education in spite of detailed study and researches on programs. Attitudes and beliefs about new curriculum in general have been also largely derived from the reportages or pres conferences instead of curriculum texts. The expectation was that the new curriculum and teaching material for elementary education would be used throughout the country. Taking into consideration of the resulting' guidelines for elementary education curriculum media has approve and published the views and critics of National Ministry o Education. Although there is common agreement about the limitations of this new reform and curriculum, there has been less agreement about the points of experts and program developers except National Ministry of Education. In spite of these limitations, it is revealed that there have been great discrepancies among the reality and the situation that were appeared on the media. They paid attention only the slogans of program developers. However, close collaboration between program developers, researchers and teachers can greatly facilitate this process and can be accomplished in a variety of ways. Just few of media only elicited the results of studies and opinions of educational experts. So the media have not reflected explicit feedback from students, parents, teacher even the principals. They did not provide people with direct evidence of the results of their efforts and illustrate precisely the improvements made in students' learning. The most elusive parts of curriculum have not been placed on the discussions on Media due to inadequate technical infrastructure of the journalists. 


\section{Yeni İlköğretim Programlarının Basına Yansımaları}

\author{
İsmail GÜVEN*
}

\section{Canay DEMIRHAN IŞCAN**}

ÖZ: İlköğretim programları 2004 yılında reform adı altında yeniden düzenlendi. Konuyla ilgili haberler hem tutucu hem de liberal eğilime sahip çok çeşitli basın organlarında yer aldı. Basın kuruluşları yeni programları özellikle resmi otoritelerin anlattığı ve yansıttığı biçimiyle tanıtma rolünü başarıyla gerçekleştirdi. Bu çalışma, reform adı verilen program düzenlemelerinin tanıtıma yönelik kısmını ele almaktadır: Medyada yer alan özellikle gazeteler yoluyla programın tanıtılma çabaları ele alınmıştır. Çalışmanın temel bulguları, belgesel taramadan elde edilen bilgilerin yanı sıra, gazetelere yansıyan tartışma ve haberlere dayalıdır. Günlük gazetelerin çoğunluğu programı tanıtırken uzmanlarla konuşup, araştırma yerine Milli Eğitim Bakanlığı'ndan otoritelerle yapmış oldukları görüşmeleri yansıtmış ve daha çok programların popüler boyutuna değinmişlerdir. Program geliştirenlerin kullandıkları sloganları haber başlı̆̆ı olarak vermişlerdir. Çok azı eğitim alanında çalışan uzmanlar ve yapılan araştırmalara dayalı olarak sonuçları ele alıp işlemişlerdir.

Anahtar Sözcükler: Basın, ilköğretim, program

\section{Giriş}

Toplumdaki hemen herkes bir biçimde okulla etkileşime girmiştir. Kendisi okuldan yararlanmayanlar bile yakınları aracılığıyla eğitim programları hakkında doğru ya da yanlış bilgi sahibidir. Program, okullarda ne öğretileceği sorusuna bir ölçüde karşıllk verir. Ne öğretilmesi gerektiği tartışma konusu olduğu için, programlar farklı amaç ve bağlamlara göre

\footnotetext{
* Doç.Dr. Ankara Üniversitesi Eğitim Bilimleri Fakültesi İlköğretim Bölümü Öğretim Üyesi **Araş.Gör Ankara Üniversitesi Eğitim Bilimleri Fakültesi İlköğretim Bölümü Araştırma Görevlisi
} 
biçim almaktadır. Okulda karşımıza gelen kitap, metin ya da materyaller aslında programın geçirdiği evrelerde (geliştirme, uygulama ve değerlendirme) öğrencilerin neyi öğrenmesi gerektiğine karar verenlerin düşünceleri, inançları ve değerlerinin sonucunda oluşur. Bunun da ötesinde, program geliştirme süreçleri programla uğraşanların sosyo-politik gereksinimlere karşılık vermelerini de zorunlu kılar. Hem program geliştiriciler hem de karar vericiler farklı kanallarla uzlaşıya varırlar. Değişim de işte bu noktada başlar.

Programlar sınıf ortamına gelinceye kadar farklı aşamalardan geçer. Bunlardan ilki, toplumsal evredir. Bu aşamada programlar öğrencilerden uzaktır. Politikacılar, farklı grupların ve uzmanların görüşlerinin oluştuğu bu evreyi farklı yönlerden etkilerler (Sowell, 2005). Bütün bu evrelerdeki görüşler doğrultusunda eğitim programları belli ölçüde biçimlenir. $\mathrm{Bu}$ noktada eğitim programı ve öğretim programı kavramlarını açıklamak yerinde olacaktır. Eğitim programı, bireylere okulda ve okul dışında planlanmış etkinlikler yoluyla sağlanan yaşantılara ilişkin durumların tümüdür (Saylor ve Lewis (Akt.Demirel, 2004) eğitim programını, eğitilecek bireylere öğrenme yaşantıları kazandırma planı olarak tanımlamışlardır. Gagne ise, eğitim programında konu alanını içerik, hedeflerin ifadesini de gözlenebilir davranış olarak belirtmiş, programda içeriğin düzenlenmesinin ve öğrencilerin giriş becerilerinin ön değerlendirilmesinin birlikte ele alınması gerektiğini önermiştir. Eğitim programını soyut bir belge olmaktan çıkarıp, somut ürün ya da yaşantılara dayandırmıştır. Eğitim programı hedef, içerik, eğitim durumları ve değerlendirme öğeleri arasındaki dinamik ilişkiler bütünüdür. Bütün bunlar tasarlanırken bilim, toplum, öğrenen (birey), konu alanı ve doğa kaynak olarak göz önünde tutulur (Demirel, 2004; Ornstein \& Hunkins, 1998; Sönmez, 2001).

Eğitim programlarının temel özelliği sürekli değişime açık olmasıdır yani döneme ya da çağa göre yeniden geliştirilmesidir. Programların geliştirilmesi yalnızca eğitimcileri değil, bir bütün olarak toplumdaki her bireyi doğrudan etkiler; çünkü birey toplumun bir parçasıdır ve yaşamının her anında eğitimle iç içedir. Toplumlar sosyo-kültürel, ekonomik, bilimsel gelişmeleri sürekli yaşadığı için programların da geliştirilmesi kaçınılmazdır. Program geliştirmenin genel olarak aşamalarına bakıldığında ise şu ortak noktaların belirlendiği görülür: İhtiyaçların belirlenmesi, genel hedeflerin belirlenmesi, içeriğin oluşturulması, programın denenmesi, izlenmesi, değerlendirilmesi ve değerlendirmeye göre programa son halinin verilip programın uygulanması. (Demirel, 2004; Ornstein \& Hunkins, 1998; Sönmez, 2001). 


\section{Kitle İletişim Araçları ve Ĕgitim}

Öğrencilere nelerin öğretilmesi gerektiği konusunda tartışmaların yaşandığı aşamada ise en önemli görüşler kamuoyundan gelmektedir. Kamuoyu ise basın yayın organlarıyla yani kitle iletişim araçlarıyla güç bulur. Günümüz modern dünyası, kitle iletişim araçlarına bağımlı duruma gelmiştir. Gazete, dergi, sinema ve televizyon gibi araçlar çoğunlukla haber ya da eğlenceyle bağlantılı olarak ele alınır ki bu anlayış yanıltıcıdır. Çünkü kitle iletişim araçları yaşantımızın her alanını, eğitim, kültür hatta tutumlarımızı bile etkiler. Ekonomi, siyaset ve bilimsel yenilik ile haberler önce bu araçlarda yer alır. Giddens (2005)'e göre. Kitle iletişim araçları günlük yaşantımızı deyim yerindeyse sarar ve sarmalar. Tutumlarımızı belli bir biçimde etkilemesinin yanı sıra, yaşantımızı doğrudan ya da dolaylı biçimde etkileyen bilgilere ulaşma yolları da sağlar. Örneğin seçimler, politik tercihler ya da bireylerin birinci elden ulaşamadığı raporlar, çoğunlukla kitle iletişim araçlarıyla etkili biçimde iletilir. Bu açıdan basın kendine özgü rolleri de üzerinde taşır. Yazılı basının temelini oluşturan gazeteler ise kitle iletişim açısından günlük gelişmeleri haber, reklam ve röportaj formatında okuyucularına sunar. Kuşkusuz TV ve internetin yaygınlaşmasıyla gazetelerin gücü azalmıştır; ama iletişim alt yapısı yetersiz olan Türkiye'de halen gazeteler birinci elden bilgi vermeyi sürdürmektedirler. Bireyler gazetelerde verilen haberleri okuyarak, yorumlayarak hem bilgilenmekte hem de tutumlarını belirlemektedirler. Basın, aynı zamanda bireyleri aydınlatma görevini de üstlenmiştir.-bu cümle çıkarılacak

2005 yılı ortalarında Türkiye' de eğitim-öğretim ve program geliştirme alanında çalışanlar, "yeni ilköğretim müfredat programı" adı altında yapılan çalışmalarla karşı karşıya kaldılar. Bu programla ilgili düzlenmelerin resmi olarak ilk adresi Milli Eğitim Bakanlığı'nın (MEB) gazetelere ve haber kanallarına vermiş olduğu bilgilendirmeler olmuştur. "Program reformu" adı verilen bu çalışmalar yeni bir program anlayışının getirilmesi, programın felsefesinin değiştirilmesi, hedeflerin, içeriğin ve yaşantıların yenilenmesi, programın düzenlenmesine ve uygulanmasına ilişkin modellerin değiştirilmesi, eğitim-öğretimde öğrenci merkezli yöntemlerin kullanılması, programda kullanılacak araç gereçlerin yenilenmesi ve programda yer alan değerlendirme araçlarının değişmesi başlıkları altında özetlenebilir. Aslında programların yenilenmesi çalışmalarına Cumhuriyet'in ilk yıllarında başlanmıştır. 1924'te Türkiye'ye davet edilen John Dewey'in hazırladığı rapor doğrultusunda daha çok ilköğretim programlarının geliştirilmesine ağırlık verilmiştir. Cumhuriyet'in ilk yıllarından sonra da kapsamlı olarak 1948, 1962 ve 1968 'de program geliştirme çalışmaları yapılmıştır. 1997 
yılında da, ilköğretim 8 yıla çıkarılmıștır (Akyüz, 2006). Bu çalışmalardan sonra da bazı düzenlemelere ve uygulamalara gidilmiştir. Bununla birlikte, 2005 programını hazırlayanlar, anlayış ve yöntem olarak diğer programlardan farklı yollar izlemişlerdir. Aslında program geliştirme dinamik bir süreçtir. İlköğretim programlarının yenilenmesi sırasında MEB, Türk toplumu, kültürü ve ulusal gelişme gibi temel ölçütlerin/kavramların göz önünde bulundurulduğunu ifade etmiştir (MEB, 2005). Bu öğeler yeni ilköğretim programlarının birleştirici unsurları olarak açıklanmıştır. Bütün bunlara karşılık MEB, aksiyon projeleri oluşturmak yerine yeniliği basın aracılığıyla verilecek haberlere dönüştürmüştür. Böylece yeni programın ülke düzeyinde tanıtımını yapmayı ummuş, buna Türk basını da kayıtsız kalmamıştır.

Türkiye' de 2004 yılından itibaren başlanan ve adına "Reform" denilen çalışmalar, basında geniş yankı bulmuştur. Bireyler hatta bazı eğitimciler de programa ilişkin ilk verileri basından elde etmişlerdir. Programın kitlelere duyurulması sırasında, basının aldığı tavır burada araştırılmaya değer özellikler göstermektedir. Türkiye'de, özellikle yeni bir siyasi, ekonomik ve kültürel oluşum olan Avrupa Birliği'ne uyum amaciyla toplumsal yaşamda ve toplumsal sistemlerde oldukça kapsamlı değişimlerin gerçekleştirilmesinin zorunlu olduğu bir dönemde, eğitim basamaklarında yapısal düzenlemelerin yapılması ve bu düzenlemeler doğrultusunda eğitim programlarının geliştirilmesi ve yenilenmesi gereksinimi vardır. 2005-2006 öğretim yılından itibaren ülke düzeyinde uygulanmaya konulan "Yeni İlköğretim Programı"nın bu gereksinime dayandırıldığı kuşkusuzdur. Bu çerçevede, programın "öğrenci merkezli" ya da "yapılandırmacı" yaklaşımdan hareketle, etkinlik temelli, öğrencinin öğrenme sürecine aktif olarak katılmasını amaçlayan, dersler arası yatay ve dikey ilişkileri dikkate alan, sınıf içi ve sınıf dışı öğrenme deneyimlerini bütünleştirmeye önem veren bir anlayışla geliştirilmeye çalışıldığı görülmektedir. Bu özellikler dikkate alındığı zaman "yeni program"ın, ilköğretim düzeyindeki eğitime önemli katkılar getirme potansiyeli olduğu söylenebilir. Ancak, bu programın hazırlanması aşamasında, program geliştirme süreci ve ilkeleri yönünden önemli eksiklerin olduğu ve uygulamada ciddi sorunların yaşandığı da bilinen bir gerçektir (EPÖ. PG. Profesörler Kurulu Yeni İlköğretim Programını Değerlendirme Toplantısı (Eskişehir) Sonuç Bildirisi 2005). Örneğin Gözütok vd (2005) yapmış oldukları araştırmada, program geliştirme sürecinin kavramsal yapıdan uzak, karmaşık ve uzman olmayan kişilerce gerçekleştirildiğini vurgulamaktadırlar.

Özellikle yazılı basın, yeni hazırlanan ilköğretim programlarını geniş bir yelpaze içinde ele alıp toplumu bilgilendirmiştir. Bu yelpazenin en ilginç 
noktası, görüş bildirenler arasında farklılıklar görülmesi olmuştur. Eğitimle doğrudan ilgilenen köşe yazarlarından, gazetelerdeki ekonomi köşe yazarlarına hatta spor yazarlarına ya da magazin yazarlarına kadar herkes görüşlerini gazetelerde bildirmiştir. Türkiye açısından oldukça önemli ve bir o kadar da çelişkili olan bu durum sıradan insanların düşüncelerinin de karışmasına yol açmıştır. Basın mensupları ya da çalışanları, programı hazırlayanların planladıkları toplantılara katılarak halkın program konusunda genel bir fikir edinmesini sağlamaya çalışmışlardır. Basın, aynı zamanda, bilim adamları ile politikacıların da üstü kapalı olarak tartıştığı bir ortama dönüşmüştür.

MEB, basına yansıyan açıklamalarında görüşlerini şöyle açıklamaktadır: Milli Eğitim Bakanlı̆̆ Talim ve Terbiye Kurulu, ilköğretim okullarında öğrenimine devam eden öğrencilerin öğrendiği temel bilgi ve becerilerin, gerçek hayattaki ihtiyaçlarıyla örtüşmesi için harekete geçmiştir. Milli Eğitim Bakanlığı Talim ve Terbiye Kurulu, öğrencilerin yaparak ve yaşayarak öğrenmesini, öğrendiklerini gerçek yaşamla bütünleştirmesini amaçlayan yeni ilköğretim programlarını hazırlamıştır. Yeni ilköğretim programlarında öğrencilerin derse aktif katılımı hedeflenmiştir. Milli Eğitim Bakanı, yeni programın temel özellikleri ile ilgili olarak öğrencilere kazandırılması gereken 8 becerinin belirlendiğini, yapılandırmacı yaklaşımın benimsendiğini, sadece öğretimin değil eğitimin de üzerinde önemle durulduğunu, iyi birey ve iyi vatandaş, sorgulayan, düşünen, analiz ve sentez yapabilen bireyler yetiştirmenin amaçlandığını belirtmiştir (MEB, 2005).Yeni program, 2004-2005 öğretim y1lında belirlenen pilot illerde uygulanmaya başlamıştır. Pilot uygulama sonucunda programlarda ciddi bir düzeltme ve yenileme yapılmadan, taslak programa göre yazılmış kitaplarla, 2005-2006 öğretim yılından itibaren programlar, Türkiye genelinde uygulamaya geçirilmiştir. MEB, büyük bir gizlilikle hazırladığı bu "reform" program taslağını birkaç fakülte ile bir sivil toplum kuruluşuna (Türkiye Yazarlar Birliği) göndermek, kısmen de olsa ilgililerin görüşlerine başvurmak zorunda kalmıştır. Çünkü program 2005yılından itibaren uygulamaya konacaktı ve kamuoyu desteği ile alanda çalışanların tepkisini çekmeye başlamıştı. Resmi olmayan eleştirileri karşılamak zorunda kalmışlardı. (Bkz. Milliyet 16.09.2004, Sabah 10.08.2004, Hürriyet 05.09.2004, Sabah 12.08.2004 vd.). Doğal olarak burada "geliştirme" ve "reform" kavramları çoğunlukla birbirine karıştırılmıştır. "Reform" kavramının kelime anlamına bakıldığında, "daha iyi duruma getirmek için yapılan değişiklik, iyileştirme, düzeltme, 1slahat" olarak tanımlandığı görülür. Reform, yeniden biçimlendirme, yeniden şekillendirmedir (Ornstein and Hunkins, 1998; TDK, 27.11.2005). Oysa ki, yeni programlar reform 
olmaktan çok uyarlama niteliği taşımaktadır. Bu çalışmalar bilimsel olarak ele alınmaktan çok basın yayın kurumlarının verdikleri haberlere dönüştürülmüştür.

Program geliştirme çalışmaları için öncelikle yapılması gereken bilimsel tartışmalar programı hazırlayanlarla karşı olanlar arasındaki anlaşmazlıklar ve fikir ayrılıkları, karşılıklı atışmalar ve röportajlar biçiminde gazetelere yansımıştır. Eğitimde program geliştirme çalışmalarında temel hareket noktalarından birisi, uygulanmakta olan eğitim programlarının, toplumdaki ekonomik, sosyal ve siyasal, kısaca kültürel gelişmeler ve değişimler ile bilim ve teknoloji alanındaki gelişmeler doğrultusunda ortaya çıkan yeni bireysel ve toplumsal gereksinimleri karşılama durumlarının değerlendirilmesi araştırmalarından elde edilen verilere dayandırılmasıdır. Ancak, "Yeni İlköğretim Programı"nın hazırlanmasında, önceki programın uygulayıcılarından ve uygulama sonuçlarından bilimsel bir süreç içinde dönütler alınmadığı görülmektedir (EPÖ. Profesörler Kurulu, 2005). Aslında daha önce yapılan programlar 1962, 1968 ve diğer programların hiçbiri basında bu kadar yankı bulmamıştır. Burada o zaman basın-yayın organlarının bugünkü kadar gelişmemiş ve iletişim ağının yaygın olmamasının etkisi olsa da yazılı basın açısından geniş yer verilmediği incelemelerden ortaya çıkmıştır (Akyüz, 2006).

\section{YÖNTEM}

$\mathrm{Bu}$ araştırmanın amacı, Türk Eğitim Tarihi açısından oldukça önemli olan, kamuoyundaki yeni ilköğretim programı ile ilgili görüşleri, belli başlıklar altında ele alıp değerlendirmektir. Araştırmada, değişkenlerin tek tek, tür ya da miktar olarak oluşumlarının belirlenmesi için, genel tarama modellerinden, tekil tarama modeli kullanılmıştır. Bu tür bir yaklaşımda ilgilenilen olay, madde, birey, grup, kurum, konu vb. birim ve duruma ait değişkenler, ayrı ayrı betimlenmeye çalışılır (Karasar, 1999).

Çalışmada, ulusal basının farklı anlayıştaki gazeteleri (Cumhuriyet, Milliyet, Hürriyet, Sabah, Zaman, Yeni Şafak, Evrensel vd.) taranarak haberler ortaya çıkarılmış, farklı ideolojileri benimseyen basın yayın organlarının haberlerine de yer verilmiştir. Tartışmaların yoğun olduğu 2004-2006 yılları arasında basın yayın organlarını yansıyan görüşler değerlendirilmiştir. Yöntem olarak ele alınan haberler özetlenmiş ve temel noktalardaki tartışmalara yer verilmiştir. Yalnızca haber niteliği taşıyan ve programa ilişkin görüş yansıtmayan ya da aynen tekrar eden haberler ya da yayınlar dışarıda bırakılmıştır. Bulgular aşağıdaki başlıklar altında özetlenmiştir. 


\section{Yöntem ve Yaklaşım Üzerine Tartı̧̧malar}

Program üzerine yapılan tartışmaların ve haberlerin çoğunda öne geçen konu, uygulanacak yöntemlerin günümüz Türkiye'sinde eğitim sistemine egemen olan ezberciliğin ortadan kalkacağı noktası olmuştur. Ezberciliğin ortadan kalkacağına ilişkin haberler, taranan haberlerin bütününde yer almıştır. Bu aslında, Talim Terbiye Kurulu ve Milli Eğitim Bakanlığı'nın da programın değişmesinde temel aldıkları bir noktadır. Türkiye'nin uluslar arası standart sınavlarda (PISA, TIMSS) gösterdiği başarısızlıkların nedeni olarak gösterilen ezberciliğin, yeni hazırlanan programlar aracılığıyla ortadan kaldırılacağı belirtilmiştir. Bu konu gazetelere aşağıdaki biçimde yansımıştır:

"Talim ve Terbiye Kurulu (TTK) ilköğretimin Hayat Bilgisi, Matematik, Sosyal Bilgiler, Fen ve Teknoloji ile Türkçe programlarını yenilerken, ezberci eğitimden uzaklaşılması amaçlandı. Öğrencilere problem çözme, eleştirel ve yaratıcı düşünme, araştırma-sorgulama, Türkçe'yi etkili kullanma, girișimcilik, iletişim becerileri kazandırılması hedeflendi." Abbas Güçlü, Milliyet gazetesi, 16.09.2004.

“...Çocuklara derste iyi not almaktan başka değerlerin olduğunu ögretecek bir sisteme geçileceği anlaşıllyor. Bütün dersleri 10 olan ama yaşamdan zevk almayan, tek derdi elindeki metinleri ezberlemek, testlerde başarılı olan gençler yetiştirme döneminin sonunu işaret ediyor çünkü bu. Bu aynı zamanda gençlere bir karşılık vermeden bir yardımda bulunma duygusunun aşılanacağı anlamına geliyor. Çocukları yaşlılara, hastalara, kimsesizlere yakınlaştıracak bir model bir aksilik olmazsa önümüzdeki yıl bütün Türkiye'de hayata geçeceğe benziyor...” Ergun Babahan, Sabah gazetesi, 10.08.2004.

"Tam 64 yıl boyunca değişime direnen ilköğretim müfredatı değişti. Artık okullarda tek renk, tek ses yaklaşımını benimsetmek yerine, çoğulcu bir dünyaya alışkın bireyler yetiştirilecek. Ezbercilikten vazgeçilip yaratıcı düşünce ön plana çıkarılacak..." Nuran Çakmakçı, Hürriyet gazetesi, 05.09.2004.

“...yeni ilköğretim müfredatında, kitaplarla "bilgi yığını" verilemeyecek, böylece öğrenciler kitaplarda yazılan bilgileri “ezbercilik"le öğrenmeden kurtulacak..." Dilek Güngör, Radikal gazetesi, 11.08.2004.

“...Milli Eğitim Bakanlığı sadece müfredatı yenilemedi, eğitimöğretim felsefesini değiştirdi. Öylesine önemli ki bu dönüşüm, 
Türkiye'nin yarınlarını etkileyecek...Yoğun bilgi yerine öğrencinin araştırıp bilgiye ulaşacağı ipuçlarının verildiği kitaplar aldı...Çocuklarımızın yarının ihtiyaçlarına ve koşullarına göre hazırlamasını sağlayacak bir yaklaşım bu...” Erdal Şafak, Sabah gazetesi, 11.09.2005.

“...Direkt öze dönük, yani öğrenciyi bilgi deposuna dönüştürmek yerine analitik, senteze dayalı eğitime yönlendirmeyi hedefleyen yeni eğitim sisteminin daha başarılı kuşaklar yetiştireceğine şüphe yok." Mustafa Ünal, Zaman gazetesi, 11.08.2004.

“...Yeni eğitim rüzgârı ilkokul çocuklarının bile beyin fırtınası tekniğini öğrenerek yetiştirilmesini öngörüyor. Öğrenci, doğruların değişebileceğini öğrenerek, üretici ve mucit düşünceleri geliştirerek, problem çözme yeteneğine sahip kılınmaya çalışılmakta; bilginin "niçinler" ve "başka bilgilerle bağlantıları" bilinerek öğretilmektedir..." Prof.Dr. Osman Çakmak, Zaman gazetesi, 19.08.2004.

Bütün bunlardan Türk eğitim sistemine ilgi duyanların sisteme hakim olan ezbercilik sorununa, programın çözüm getireceği konusunda fikir birliğine vardıkları görülmektedir. Oysa ki, yöntem konusunda yeni programlarda kavram karmaşası vardır. Yöntemler birbirine karıştırılmış, teknik kullanımları yeterince açıklanamamıştır. Bunun da ötesinde tanıtım kitapçığında bile bütün bunlar yanlış örneklenmiştir (Gözütok vd. 2005). Örneğin yapılandırmacı yaklaşım, aktif öğrenme yöntemleri ya da öğrenen merkezli yöntemler biçiminde açıklanmıştır.

Basının, öğretmen ve halkı bilgilendirirken teknik kavramları yerinde kullanmadıklarını ya da anladıkları gibi verdiklerini görmekteyiz. Dramatizasyon yerine yaratıcı drama, görüş geliştirme yerine örnek olay yöntemi gibi yanlışlar oldukça yaygındır. Basın, , kendi eğitimleri ya da çocuklarının eğitimlerini değerlendirmelerinden yola çıkarak dile özellikle eski programlardaki aşırı bilgi yığmaca konusuna da göndermeler yapmıştır. Bir diğer nokta da hiçbirinin "müfredat" kavramını düzeltme gereksinimi duymamasıdır. Bu kavram, daha çok, okutulacak ders ya da ders listesi anlamındadır. Doğrusu, yabancı kökenli "program" ya da Ertürk tarafından önerilen "yetişek" olarak verilmemiştir. Dolayısıyla basında yer alan haberlerin bazılarının yazar tarafından yorumlanarak verilmesi yerine, programı tanıtanların basina ilettikleri metinlerden haber yaptıkları söylenebilir. Burada başka bir nokta da basının kullandığı söylemdir. Basın söyleminin yayın yönetmenleri, yayıncı kuruluşlar ve haberi yazan köşe yazarlarının düşüncelerine göre biçimlendiğini de görmekteyiz. Çünkü, bazı 
yayın organlarında programların çok yararlı olduğu söylenirken, ideolojik boyutuna hiç değinilmemiştir. Diğger yandan, başka bir yayın organında katı tutucu siyasi söylemin yansıdığını görmekteyiz. Bu söylem aynı zamanda, toplumun genel bilincini de etkilemiştir. Öğretmenlerin gerçekten ne düşündüğünü çok az ya da hiç ele alınmamıştır. Örneğin yapılan araştırmalarda, öğretmenlerden birçoğu programı basından öğrendiklerini söylemişlerdir (Yazarların hizmetiçi eğitim çalışmalarındaki fikir taramalarından ortaya çıkan sonuçlardır, araştırma sonuçları henüz yayımlanmamıştır). $\mathrm{Bu}$ konuyu biraz daha ileride ayrıntılı olarak tartışacağız.

\section{Programin Felsefesi ve Hedefleri}

Eğitim programları belli bir felsefeye göre oluşturulur ve uygulamaya konur. Programın felsefesi, "nasıl bir insan yetiştirmek istiyoruz?" sorusunu cevaplamamıza yardımcı olur. Hedefler ise, program aracılığıyla ulaşmak istediğimiz noktayı gösterir (Demirel, 2004). Gerçi yeni programda hedef kavramı artık kullanılmamakta yerine hedefleri de içeren "kazanım" kavramı kullanılmaktadır. Kazanımın teknik yönünü bir tarafa bıraktığımızda programın hedefi kendiliğinden ortaya çıkmaktadır. Basına yansıyan görüşlerde yer alan ve yinelenen kavramlarda, demokratik değerlere bağlılık, iyi insan, iyi vatandaş ve demokrasi eğitimi gibi noktalara yer verildiğini görmekteyiz. Bu görüssler aslında programın felsefesinin yalnızca popüler boyutunu yansıtmaktadır. Çünkü programın temelini oluşturan "değerler ve beceriler" incelenmedikçe gerçek felsefeyi ortaya çıkarmak oldukça güçtür. Bununla ilgili basına yansıyan görüşler şöyledir:

"İyi birey, iyi insan, iyi vatandaş yetiştirme temelindeki müfredatta Atatürk ilke ve inkılâpları öğrencilere sadece bilgi olarak değil, yaşatılarak öğretilecek. Örneğin, Türkiye'nin coğrafi bölgeleri ele alınırken, milli mücadele yıllarında bu bölgelerde yaşanan olaylara yer verilecek. Matematik dersinde de Atatürk'ün geometri çalışmaları anlatılacak. Öğretmenin rehberliğinde öğrenciler aktif olacak” Abbas Güçlü, Milliyet gazetesi,16.09.2004.

"Okul yönetimi ve öğretmenler, öğrencilere yalancı, tembel, güvenilmez bireyler oldukları mesajı veremeyecek...” Abbas Güçlü, Milliyet gazetesi,16.09.2004.

"Yeni ilköğretim müfredatında, Sosyal Bilgiler dersinde uygulamalı demokrasi eğitimi verilecek. Öğrenciler, meclis oluşturacak, hükümet kuracak, Anayasa ve haklar sözleşmesi hazırlayacak. ....Sosyal Bilgilerde ögrencilere etkinliklerle sivil toplum kuruluşlarının görevleri anlatılacak...."bilinçlendirme kampanyası" etkinliğiyle 
toplumsal duyarlık ve katılım bilinci yerleştirilmeye çalışılacak... Yeni müfredatla öğrencilere, suçluluk duymaksızın "hayır" diyebilmeleri ve nedenini açıklayabilmeleri öğretilecek...” Dilek Güngör, Radikal gazetesi, 17.08.2004.

“...Eğitimde küreselleşme ve ulusallaşmanın iki çatışma alanı olduğunu kabul eden Milli Eğitim Bakanlığı, temel eğitimde ulusallaşmayı ön plana çıkaracak. İlköğretim öğrencilerinin okuyacağı ders kitaplarında "milli kültür ve Anadolu kültürü" anlatılacak...Öğrencilere hoşgörü Mevlana'dan örneklerle anlatılacak..." Dilek Güngör, Radikal gazetesi, 17.07.2004.

Yeni ilköğretim programında, öğrencinin derslerde akademik anlamda başarılı olmasının yanı sıra, çeşitli sosyal hizmetlere katılması da önemli bir yer tutmaktadır. Bu özellikle ilgili olarak da basında görüşler yer almıştır.

"Milli Eğitim Bakanlığı bir ilke imza atarak, zorunlu da olsa ilköğretim öğrencileri için 'gönüllü çalışma' projesini uygulamaya koyuyor. İlköğretim öğrencileri huzurevleri, çocuk yuvaları ve hayvan derneklerinde "zorunlu gönüllü" olarak çalışacaklar. Gerekli "hizmet saatini" doldurmayan öğrenci karnesini alamayacak.” Pervin Kaplan, Sabah gazetesi, 09.08.2004.

Burada önemli olan noktalardan birisi, program temelinin yurt dışından alınmış ilkelere dayandırılmış olmasıdır. Programda yapılan teknik yanlışların gazetelere yansımadığı ya da MEB uzmanlarınca dikkate alınmadığı bir gerçektir (Gözütok, 2005a). Kazanımların yurt dışındaki kitaplardan alınmasından dolayı özellikle dinsel ve geleneksel farklılıkların program üzerinde yama gibi durduğu gözlemlenmiştir. Öğretmenlerin bu konudaki görüşleri alınmamıştır.

“...Sosyal Bilgiler programıyla; AB, ABD ve dünya sistemine daha uyumlu duruma getirilmeye çalışılan Türkiye'nin, bu sistem için gerekli "bireyler" -olayı biraz karikatürize edersek kapitalist sistemle "uyumlu ve istenilen"- yetiştirilmek istendiği anlaşılıyor...Yeni Sosyal Bilgiler programımızın öğrenme alanları, neredeyse tamamen National Council for the Social Studies'in (Sosyal Bilgiler Ulusal Konseyi) programındaki on tematik standarttan alınmış olmasına karşın, kaynakçada ya da kitabın herhangi bir bölümünde belirtilmemiş...Bunun yanında bir de 5. sınıf öğrencilerine programda "akademik dürüstlük" değeri kazandırılacağı belirtilmiş. Tam da bize özgü trajikomik bir olay!..." Ahmet Derviş, Evrensel gazetesi, 11.09.2004. 
Türkiye'deki eğitim sisteminin işe yaramaz öğrenciler yetiştirdiği söylemi, varolan eğitim kültürünün küçümsenmesine yol açmıştır. Neoliberal söylemin ürünü olan bu ifadeler aslında, değişim konusunda bilimsel gerçeklerden çok popüler gerçeklere dayandırılmıştır. Öğretimin özünün ve öğreticilerin demokratik ortam sağlamadığı bir kültürde, özgür düşünme ve katılımcılığın gerçekleşmesi basit sloganlara indirgenmiştir.

Bu konuda Milli Eğitim Bakanı’nın gazetelere yansıyan görüşleri oldukça ilginçtir:

\section{DEĞIŞ̧iM İLKELERİ...}

"Fikri hür, vicdanı hür, irfanı hür nesiller yetiştirmek için değişimi zaruri görüyoruz" diyen Hüseyin Çelik, değişim ilkelerini "Cumhuriyetin demokratik, laik, sosyal hukuk devleti vasfını ana çerçeve olarak kabul eden, bilimin yol göstericiliğini öne çıkaran, dünyadaki gelişmeleri dikkate alan, $\mathrm{AB}$ vizyonunu ölçüt alan katılımcı bir değişim" olarak nitelendirdi. Çelik, eğitim sisteminde "okullaşma oranı, fiziki şartlar, rehberlik sisteminin yeniden düzenlenmesi, öğretmenlerin kalitesini artırma, eğitimde teknoloji kullanımı ve müfredatın çağa uygun hale getirilmesi” konularında eksiklikler olduğunu belirterek, kız çocukların okula gönderilmesi için kampanya gerçekleştirildiğini, ayrıca verilen 20-35 milyon liralık harçlıklarla kızlara yönelik pozitif ayrımcılık yapıldığını söyledi. "Müfredatın çağın gereklerini yerine getirecek şekilde değişimi şart” diyen Çelik, "mevcut müfredatla Newtoncu, düz mantıkla 'kara ya da beyaz' diyen insanlar yetiştirildiğini, aradaki gri tonların gösterilmediğini” kaydetti. Yeni müfredatın hazırlanmasında 38 sivil toplum kuruluşundan görüş alındığını, 8 üniversitenin birikiminden yararlanıldığını ve $A B$ uzmanlarının katkı sağladığını, 53 akademisyenin de çalıştığını anlatan Çelik, 8 yıllık temel eğitim için çalışmanın bittiğini, ortaöğretim için müfredat taslağı çalışmalarının ise sürdüğünü bildirdi. Çelik, yeni müfredatın uygulanması aşamasında öğretmenlerin hizmetiçi eğitimlerinin de 5 yıl içerisinde tamamlanacağını ifade etti (Hürriyet gazetesi, 13 Temmuz 2006).

\section{YENI MÜFREDAT}

Milli Eğitim Bakanı Çelik, sözlerini şöyle sürdürdü:

"Yeni müfredat programıla katı davranışçı programdan zihinsel, yapılandırıcı bir yaklaşıma geçildi. Sadece öğretim değil, eğitim de vurgulandı. 8 yıllık kesintisiz eğitime uygun hale getirildi. AB standartları dikkate alındı. Çocuklarımızda eksik olan 8 ortak beceri belirlendi. Bunlar eleştirel düşünme, problem çözme, bilimsel araştırma, yaratıcı düşünce, girişimcilik, iletişsim, bilgi teknolojilerini kullanma, Türkçe'yi güzel kullanma becerisi." Yeni müfredatla 
hedeflenen insan tipini de anlatan Çelik, "Yeni müfredat, iyi birey, iyi insan, iyi vatandaş temelini oturmuş bir müfredat" dedi. Çelik, gazetecilerin konuya ilişkin sorularını da yanıtlayarak, Anayasa'da mecburi olan Din Kültürü ve Ahlak dersinin yeni müfredatta da mecburi olarak okutulacağını belirterek, ancak kitaplara Aleviliğin ne olduğu ve olmadığı konusunda bilgilerin konulması için çalışmaların sürdüğünü kaydetti. Hüseyin Çelik, bazı gazetelerde "Çarpım tablosu artık ezberlenmeyecek" şeklinde haberlerin yer aldığını da hatırlatarak, "Çarpım tablosu yine ezberlenecek. Ezberci eğitim olmayacak demek farklı, bu farklı" diye konuştu. "Yeni müfredatın da sonu YÖK Tasarısı gibi mi olacak?" şeklindeki soru üzerine ise Çelik, "YÖK'ün değişmesi de kaçınılmazdır. Orada da mesele farklı noktalara çekildi. YÖK'ün değişmemesi yükseköğretimin sorunlarını çözmedi" dedi.

Çelik, ÖSS ve LGS'de pek çok öğrencinin "sıfır" almasına ilişkin bir soru üzerine de, "yeni müfredat çalışmasının da bu konuda çözüm olması için yapıldığını" söyledi. Bakan Çelik, yeni müfredatın başarıya ulaşmasında en önemli faktörün "mantalite" değişimi olduğunu sözlerine ekledi. (Hürriyet gazetesi, 13 Temmuz 2006).

\section{Okuma Yazma-Öğretimi Konusu}

$\mathrm{Bu}$ noktada şu soru sorulabilir: Neden okuma yazma ayrı bir başlık olarak ele alındı? Bu tür bir sorunun cevabı kendi içinde gizlidir aslında. Okuma-yazma ilköğretim programının temelini oluşturur. Yaşamımız boyunca elde edeceğimiz diğer kazanımların tümü, bu beceri alanlarında elde ettiğimiz kazanımlara bağlı olarak değişir. Öğretmenler ve aileler için de en somut gösterge, çocuklarının okuma-yazma becerilerinde ne kadar başarılı olduğunu gözlemektir. Çünkü, okuma yazma ile birlikte, çocuk yeni bir dil geliştirir, kendini daha farklı biçimlerde ifade etmeye başlar. Okumayazma çalışmaları diğer alanların temeli olduğu için, bu alanda ortaya çıkan güçlükler ve olumsuzluklar bireylerin gelecekteki öğrenim yaşantılarını ve geleceklerini doğrudan etkiler. Bu evre ne kadar kısa zamanda ve etkili geçerse, hem öğrenci hem öğretmen hem de aileler o kadar mutlu olabilirler. Yeni ilköğretim programlarının hem yöntem, hem içerik hem de anlayış yönünden en fazla değişikliğe uğrayan alanı okuma-yazma ve dil becerilerine ilişkin düzenlemeleridir. Yeni program, deyim yerindeyse, farklı ülkelerden adapte edildiği için dil becerileri açısından büyük farklılıkları taşımaktadır. İngilizce ve Türkçe'nin tamamen farklı yapılarda olması, okuma-yazma ve dolayısıyla dil öğretimi konusunu daha da karmaşık hale getirmiştir. Dil konusunda çalışanlar, program geliştirme konusundaki teknik 
altyapı yetersizliklerinin kavram kargaşasına yol açtığını vurgulamıştır. Okuma-yazma ögretimi konusu da gazetelere hem bilim adamları hem de köşe yazarları tarafından eleştiri biçiminde yansımıştır. İlginç olan nokta, yöntemin eleştirilmesi ama çocukların fizyolojilerinin bu açıdan değerlendirmeye tabi tutulmamasıdır. Çünkü yazma temelde, küçük kas gelişimine bağlı olan bir yetenektir. Bunlar ele alınmadan yalnızca yöntemin tartışıldığını görmekteyiz. Bu noktada karşımıza çıkan en temel tartışmaları aşağıdaki biçimde özetlemek olasıdır:

26.08.2005 tarihli Yeni Şafak gazetesinde, Çukurova Üniversitesi, Eğitim Fakültesi Dekanı Yrd.Doç.Dr. Oğuz Kutlu'nun görüşlerine yer verilmiştir. Kutlu, okuma yazma öğretiminde hem tümdengelim hem de tümevarım yönteminin etkili olduğunu, ancak tümevarım yönteminin ezberciliği yok etmenin yanında parçadan bütüne gittiği için konunun ayrıntılı öğrenimini de sağladığı̆ı belirterek, yeni müfredatı olumlu karşıladıklarını belirtmiştir.

15.09.2005 tarihinde Cumhuriyet gazetesi, okuma-yazma öğretimi ile ilgili Prof.Dr. İbrahim Ethem Başaran'nın ve Niyazi Altunya'nın görüşlerine yer vermiştir. Prof. Dr. İbrahim Ethem Başaran: "El yazısı uygulamasına okuma-yazma büyük ve küçük harflerle öğretildikten sonra geçilmesi uygundur. Bakanlığın birden bire uygulamaya koyduğu bu yöntemlerle öğrenciler zorlanacak ve okuma-yazma öğretimi gecikecektir...”

Niyazi Altunya: “...Asıl sakıncalı olan, okuma-yazmanın harf yöntemiyle öğretileceğinin açıklanmasının yanı sıra, el yazısı kullanılacak olması. Okuma-yazmanın harf yöntemiyle yapılacak olması sakıncalı bir uygulama...Psikolojik araştırmalar, çocukların öğretiminde bütünden parçaya gidişin asıl olduğuna işaret eder..."

"Yeni sistemle, yani ses temelli cümle yöntemi ile çocuklarımız sadece okuma yazma öğrenmekle kalmayıp, doğru telaffuz, akıcı konuşma ve her türlü sesi birbirinden ayırt etme yeteneği de kazanacaklarmış. Benim merak ettiğim, hayatında hiç yılan sesi ya da patlak lastik sesi duymayan bir çocuğa, bu sesi nasıl anlatacağımız. Eee o da öğretmenlerin ve anne babaların yaratıcıllı̆ına kalıyor... Diğer okullardaki çocuklar okuma yazma öğrendi, bizimki hâlâ harflerle uğraşıyor diye okul değiştiren veliler de, hâlâ hafızalarda..." Abbas Güçlü, Milliyet gazetesi,12.07.2005.

Basın yayın organlarının söylemi, yaygın görüşler çerçevesinde alınan bilgiyi halka sunma biçiminde oluşmuştur. Görüşlerini bildiren kişi ya da kuruluşlar genelde kendi bakış açılarını yansıtarak ya da bilgiyi kendilerine 
verildiği biçimiyle sunmuşlardır. Böylece "Reform" adı verilen söylem basın aracılığıyla halka benimsetilmeye çalışmıştır. Reform söylemi, bilgi, zeka, ezbercilikten uzaklaşma, iyi vatandaşlık, farklılıklara sayg, fikri hür vicdanı hür gibi temel sloganlara dayandırılmıştır. Basının söylemi ile varolan yöneticiler ve grupların söylemi üst üste gelmiştir. İlköğretim programlarında kullanılan Türkçe'nin günümüz çağdaş Türkçesi yerine, anlamları olduğu halde Arapça ya da batı dillerinden alınan kavramlara dayandırıldığını görmekteyiz. Örneğin, "ileti" yerine "mesaj”, "izlemek" yerine "takip etmek", "bulmak" yerine "icat etmek" gibi sözcükler kullanılmıştır. Bunlar iktidarın sembolik yansımalarıdır. Çünkü, özellikle tutucu iktidarların yeni üretilen Türkçe sözcükler yerine diğer dillerden gelen sözcükleri kullanmayı tercih ettikleri uzun zamandır bilinmektedir (Güven, 2000). Türkçe öğretimi bilgi edinmeye dayandırılmıştır. Oysa ki, dil her şeyden önce iletişim aracıdır. İletişim ise, dinleme, anlama, konuşma, yazma gibi temel becerilerin geliştirilmesiyle etkili olarak kullanılabilir. Program, dili etkili kullanma becerisi yerine, yalnızca okuma ve konuşma becerisiyle sınırlandırılmıştır. Ayrıca programlardaki anlatım bozuklukları ve dilsel yanlışlar da programın bütününü olumsuz yönde etkileyen diğer olgulardır. Bazı araştırmalar Türkçe programındaki sorunların alan uzmanlarının yetersizliğinden kaynaklandığını vurgulamışlardır (Gözütok vd. 2005).

\section{Öğretmenler ve Öğretim Süreci}

Basında, pilot okullarda programın denenmesi sonucunda, yeni programla ilgili öğrenci ve öğretmenlerin olumlu görüşlerine yer verilmiştir. $\mathrm{Bu}$ konudaki görüssler gazetelerde programları hazırlayanlarla yapılan bir görüşmeye dayandırılmıştır. Oysa ki, Gözütok vd. (2005) yapmış oldukları araştırmada bunun tersini bulmuşlardır. Aslında öğretmenler programın başarıya ulaşmasının temelini oluşturur. Bir program ne kadar iyi hazırlanmış olursa olsun, öğretmenler yeterli değilse başarı şansı çok düşüktür; çünkü programın kalbi bir anlamda öğretmendir. Öğretmenlerin bilgilendirilmediği bir programın başarı şansının düşük olacağı baştan kabul edilmelidir. Özellikle alt yapısı yetersiz okullarda öğretmenlerin neler yapacağı pek de belirli değildir. Sistemdeki öğretmenlerin çoğu programdaki yöntemler ve uygulamalar konusunda yeterli bilgiye sahip olmadıkları halde programın başarısını nasıl belirledikleri de ayrıca bir sorun olarak karşımıza çıkmaktadır. İlköğretimde görev yapan çok sayıda öğretmenin, öğretmenlik eğitimi veren kurumlardan mezun olmaması ya da alan dışında hizmet veriyor olması öğretim yöntemlerinin kullanılmasını olanaksız hale getirmektedir. Basında, yeni programlarla ilgili olarak öğretmen, öğrenci ve yöneticilerin olumlu görüşlerine yer verilmesinin yanı sıra eğiticilerin eğitimi ile ilgili görüşlere de yer verildiği görülmektedir. 
18.02.2005 tarihinde Radikal gazetesinde Umay Aktaş, yeni programın deneme uygulaması sırasında, pilot okullardan öğrenci, öğretmen ve yöneticilerle görüşmüş, onların programla ilgili olumlu görüşlerine yer vermiştir. Örneğin; Ecem, "Dersler eğlenceli geçiyor. Eskiden okuma parçalarını 5-10 kez okuyup anlatırdık. Çok sıkıcıydı. Şimdi okuyup tartışabiliyoruz" diyor. Beşinci sınıf öğretmeni Seval Küçük, "Çocukların derse katılımı arttı. 'Ben acaba yanlış yaptım mı' diye düşünmüyorlar, çünkü sorular yoruma dayalı. Matematik ve fen bilimlerinde eğitim araç-gereçleri çok daha farklı" diye ifade etmiş. ...İlköğretim Okulu Müdürü ... da yeni sistemden memnun: "Üç-beş öğrenci liderlik yapıyor, sınıfı sürüklüyordu. Yeni sistemde her öğrenci aktif olmak zorunda. Öğretmenler daha önce belli kalıplar içinde bildiği bilgileri küçük bir planla günü kurtarabilirdi. Ama şimdi günü kurtarmak için mutlaka birtakım araştırmalar yapmak zorunda."

“...Şimdi anlıyoruz ki, bizim Hititlerinkinden önce kendi ailemizin tarihini öğrenmeye, itaatten önce sorgulamaya, ezberlemeden önce anlamaya, farklılıkları kabullenmeye, bir arada yaşamayı içselleştirmeye ihtiyacımız var. Bilgi, ancak böyle kültüre dönüşebiliyor. Talim Terbiye Kurulu Başkanı Ziya Selçuk ve arkadaşlarının çabaları bu açıdan önemli... Tek sorun şu: Acaba Türkiye'de itiraz eden çocuğu hoş görecek öğretmenler, müdürler, veliler, valiler, komutanlar, bakanlar var mı? Yoksa işe, onların eğitimiyle mi başlamalı?" Can Dündar, Milliyet gazetesi, 14.08.2004.

Bahar Atakan (Milliyet gazetesi,17.06.2005), toplumun yeni programa hazır olmadığını "veliler program hakkında yeteri kadar bilgilendirilemedi" diyerek belirtmiştir. Ayrıca yine 22.06.2005 tarihli Radikal gazetesinde, uzmanlardan oluşan bir grubun "Yöneticilerin ve denetçilerin hizmet içi eğitim alması gerekli; aileler de yeni müfredat konusunda bilgilendirilmeli" saptamalarına yer verilmiştir.

"Yeni müfredatın AB'ye uyumlu olduğu söyleniyor. Peki AB'deki öğretmenlerin özlük hakları, sosyal yaşamları ile Türkiye'deki öğretmenlerin acaba aynı mı? Neden bu önemli durum, farklılık görmezlikten geliniyor?.. Unutulmamalıdır ki, malzeme ne kadar kaliteli olursa olsun, onu kullanacak, yemek yapacak olan aşçılar öğretmenlerdir. Lütfen yemekler çöpe dökülmek zorunda kalmasın...” Refik Durbaş'ın köşesinden, Sabah gazetesi, 30.08.2004.

"Daha çok eğitim kurumu açmadan, bu kurumlarda çalışacak yeterli sayıda ve nitelikli öğretmen yetiştirmeden ve öğretmenlerin yaşam koşullarını iyileştirmeden eğitim sistemini düzeltemezsiniz" Zeynep Kızıltepe,” Okullardaki Kısırdöngü’, Radikal gazetesi, 13.06.2005. 
Programla ilgili yer alan diğer olumlu görüşlerde ise, öğrencinin merkezde yer alarak aktif olması, öğretimde yeni yöntemlerin kullanılması gibi özellikler üzerinde durulmuştur.

"Yeni müfredatın uygulandığı pilot okullardan Kocaeli'ndeki ... İlköğretim Okulu'nda derslere girdik. Gördük ki, her şey çok değişmiş. Ama bu değişim iki hafta önce uygulamaya başlayan müfredattan değil, değișime hazır öğrenci ve öğretmenlerden kaynaklanıyor...Ölü Ozanlar Derneği'nde aktör Williams'ın etrafında bir çember oluşturan öğrencileri, öğretmenlerinin anlattıklarından ilham alırlar. Hepsi hipnotize olmuş gibidir. Bizi aynı tablonun daha gürültülü olanıyla Milli Eğitim Bakanlığı'nın yeni müfredatın uygulanması için seçtiği pilot okullardan ... İlköğretim Okulu'nda karşılaştık...” Nilüfer Kas, Tempo dergisi, 05.10.2004.

“...Milli Ĕgitim Bakanliğı çok güzel bir gayretle müfredat programlarını çoklu zeka, çoklu yetenek ve çoklu ögrenme metotları kuramına göre yeniden hazırlıyor. Dünyayı takip etmek, yarışan ve koşan dünyaya ayak uydurmak zorundayı. Yarıştan çekilen kaybeder ve ayak altında kalır. Dünya kapitalist bir düzene doğru koşuyor, kapitalizmin merhameti yoktur...” Ali Erkan Kavakl, Vakit gazetesi, 02.09.2005.

"Dünkü gazetelerde okuduğunuz gibi, bu y1l 6 pilot ilde uygulanacak yeni ilkokul müfredat1, "eleştirel" düşünen, sorgulayan, yaratıcı, çözüm getiren, girişimci, bilgi teknolojilerini kullanan çocuklar yetiştirmeyi hedefliyor. Mevcut eğitim sistemi çocuklara bu becerileri kazandırmıyor ne yazık ki...Şimdi farklı düşünen, farklı algılayan bireyler yetiştirmek için önümüzde gerçekten iyi bir fırsat çıkmış durumda..." Gila Benmayor, Hürriyet gazetesi, 13.08.2004.

Pilot okulların uygulamada karşılaştıkları sorunların ve programdan elde edilen çıktıların uygulamaya tam olarak yansımadığı açıktır. Zaten Milli Eğitim Bakanlığı da araştırmalara ya izin vermemiş ya da kendi verilerine dayalı açıklamalar yapmıştır. Oysaki, sağlıklı bir program geliştirme süreci için ön koşul, ön uygulamaların değerlendirilerek, sonuçların alınması ve daha sonra sürecin yeniden oluşturulmasıdır (Sowell, 2005). Buna karşılık, merkez örgüt bunları, programı uygulamaya koyduktan sonra yapmıştır. Bu noktada, aktif öğrenme ve öğretme yöntemleri gibi popüler konuların gazetelere yansıdığını görmekteyiz. Dahası da, yalnızca bir kaç gazetenin ancak böyle bir teknik konuyu incelediği ortaya çıkmıştır. $\mathrm{Bu}$ da, basının bilimsel çalışmalarda uzmanlardan yararlanmak yerine, çoğu eğitim alanında bilgisi olmayan muhabirlerinin katıldığı basın toplantılarındaki notları yazdığı şeklinde yorumlanabilir. İncelenen yazıların sadece birinde bilimsel araştırmaya gönderme yapılmıştır: Öğretmenlerin, MEB'e bağlı Eğitimi Araştırma 
ve Geliştirme Dairesi (EARGED) Başkanlı̆̆ı'nca yapılan değerlendirme çalışması sonucunda programla ilgili şu güçlü yönleri sıraladıkları 17.06.2005 tarihinde Bahar Atakan'ın Milliyet gazetesindeki yazısında ifade edilmiştir.

Buna göre, öğretmenler, programların şu yönlerinin güçlü olduğunu ifade etmişlerdir: "Öğrenci merkezli anlayışa uygun hazırlanması, öğrendiklerini günlük hayatla ilişkilendirmesi, eleştirel ve sorgulayıcı yaklaşım getirmesi, öğrencilerin bilgiye ulaşma becerilerini artırması, öğrencinin yaparak, yaşayarak öğrenmesi, öğrencilerde özgüven gelişimini sağlaması."

\section{Programı Hazırlayanlar ve Karar Organları}

Eğitimde program geliştirme çalışmalarında temel hareket noktalarından birisi, uygulanmakta olan eğitim programlarının hazırlanmasından sorumlu olanların program hakkındaki açıklamalarının göz önünde bulundurulmasıdır. Yeni ilköğretim programını hazırlayanların söylemlerinin gazetelere de aynı biçimde yansıdığı görülmektedir. Basında verilen haberlerin çoğunda programı hazırlayan ve karar veren uzmanların görüşleri birbirleriyle örtüşmektedir. Talim Terbiye Kurulu'nun ve Bakan'ın program tanıtımlarında kullandıkları programın küreselleşme doğrultusunda olduğu söylemleri, gazetelere yansımıştır. Programı haklı çıkarmak için kullanılan gerekçelerin aslında bir bütün olarak eğitimin genel amaçları içinde yer alan noktalar olduğu açıktır. En önemli gerekçe "iyi vatandaş", "iyi insan yetiştirmek" olarak belirlenmiştir. Ayrıca, küreselleşme konusunu da basitçe "çağı yakalama", "AB standartlarına ulaşma" biçimde gerekçelendirmeleri oldukça ilginçtir. Bu konuda basına yansıyan temel görüşleri aşağıdaki biçimde özetleyebiliriz:

12.08.2004 tarihli Sabah gazetesinde Bakan Çelik tarafından yeni ilköğretim müfredatının hedefinin iyi birey, iyi vatandaş ve iyi insan yetiştirmek olduğu; müfredat hazırlanırken, AB standartları ve Türk duyarlılığının da gözetildiği; yeni düzenlemenin, öğrencileri 'ya hep ya hiç' anlayışından uzaklaştırarak neden sonuç iliş̧isine taşımayı amaçladığı; bu ülkede banka hortumlayanların da çift diplomalı olduğu ve bu nedenle sadece öğretimin değil, eğitimin de vurgulandığı; sınıflarda artık öğretmen yerine öğrencinin daha etkili olacağı, yüzeysel davranış yerine bilgi, beceri, anlayış ve tutumların anlatıldığı ifade edilmiştir.

Milli Eğitim Bakanı, Hüseyin Çelik Mehmet Gündem'e verdiği röportajda program ile ilgili şunlara değinmiştir (Milliyet gazetesi, 
Gündemin Getirdikleri, 15.08.2004): "Katı davranışçı programdan, zihinsel ve yapılandırmacı bir yaklaşıma geçiş olacak. Siyah - beyaz diye bir şey yok artık. Çok yönlü düşünce var. Eğitimimizi ideolojiden kurtarıp bilim ve aklın mecrasına sokmak zorundayız. Yeni müfredatta farklılıklara tahammül etme anlayışı da verilecek. Küçük yaşta demokrasi kültürü aşılanacak. Eski müfredat 5 yıllık eğitime göre hazırlanmışken, yeni müfredat, 8 yıllık kesintisiz eğitime uygun hale getirildi. AB standartları dikkate alındı..."

08.09.2005 tarihinde, Hürriyet gazetesinde Milli Eğitim Bakanı, Hüseyin Çelik'in yeni programla ilgili olarak şu sözlerine yer verilmiştir: "Nesillerimizin soran, sorgulayan, düşünen, analiz ve sentez yapabilen bireyler olmasını hedefleyen yeni öğretim yöntemi ve müfredat, aslında gecikmiş bir girişimdir. Bunu başarmaktan dolayı çok mutluyuz. Eminim ki çocuklarımız yeni ders kitaplarını çok daha sevecen, çok daha dolu dolu bulacaklardır."

Talim Terbiye Kurulu Başkanı, programın sosyal hizmet boyutu üzerinde durmuştur.

09.08.2004 tarihinde Pervin Kaplan, Sabah gazetesinde Talim Terbiye Kurulu Başkanı Ziya Selçuk'un şu sözlerine yer vermiştir: "...Ancak iddia edildiği gibi öğretmen dışlanmayacak. Öğretmenin olmadığı bir sistem başarılı olmaz. Sadece bu sistemde öğrencinin aktif olduğu zaman daha fazla olacak... Çocuklar kimsesizler yurdu, gönüllü çevre kuruluşları, hayvan dernekleri, engelliler, huzurevleri gibi konularda gönüllü toplum faaliyetlerinde bulunacaklar ve gönüllü çalıştıklarını belgeleyecekler."

Programın politik boyutuna ilişkin görüşler ise çelişkili biçimde basına yansımıştır. Bunlardan biri ulusal öğelere yeterince yer verilmediği ile ilgili eleştirilerin basında yerini bulmasıdır. Buna karşılık başka bir görüş de aşırı ulusalcı öğelerin olduğu yönündedir. Bu tartışmalardan önemli bulunan ikisi aşağıda verilmiştir:

12.09.2005 tarihli Cumhuriyet gazetesinde Ulusal Eğitimciler Derneği Genel Başkanı Zeki Sarıhan'ın şu görüşlerine yer verilmiştir: “...Illköğretimde bu yıl uygulanmaya başlanan yeni müfredat ise Avrupa Birliği'nin isteği doğrultusunda, birey merkezli, sivil toplumcu, çok kültürlü, çok dinli bir anlayışla hazırlanmış bulunuyor. Soros Vakfı'nın ekonomik desteğiyle hazırlanan yeni müfredatta ulusal öğeler olabildiğince aza indirilmiştir..."

Yeni Aktüel dergisi, 26.09.2005 tarihli sayısında Prof.Dr. Halil Berktay'ın Sosyal Bilgiler dersi ile ilgili görüşleri özetlenmiştir: 
“...Öğretmenin rolü değişiyor; eskisinden çok farklı düşünmesi ve çok yaratıcı biçimde derse hazırlanması ve ezberletici değil öğrenmeyi kolaylaştıran insan olması gerekiyor... İstiklal Harbi çok ayrıntılı, o yaştaki çocuk bu bilgileri algılayamaz; ancak ezberleyebilir...Eskiye göre yumuşatılmış da olsa ülkeler, ideolojik Türk milliyetçiliği açısından ele alınmış...Komşularımızla birlikte yaşadığımız dünyanın bu bölgesinden ve atmosferinden kaçıp, komşularımızı ve çocuklarını tanıtmaya yanaşmıyor bu anlayış..."

Fiziki ve Teknik Altyapı Sorunu

Yeni programla ilgili belirlenen olumsuzluklar da basında yer almıştır. $\mathrm{Bu}$ görüşlerde özellikle, program için okulların alt yapısının yeterli olmadığı, öğretmenlerin yeterince bilgilendirilmediği, programın ekonomik açıdan öğretmen ve öğrenciler için yük getireceği, programın Amerikan eğitim modellerinden alındığı vurgulanmıştır. Programa yönelik getirilen eleştirilerde hem programın uygulayıcıları ve programdan etkilenenlerin yeterince bilgilendirilmemesi hem de fiziki ve teknik imkânların yetersiz olması vurgulanmıştır. Aslında eğitim programlarının uygulamaya geçirilmesinin en önemli koşullarından birisi de fiziki olanaklardır. ABD ve diğer ülkelerden değiştirilerek alınmış olan programların başarılı olabilmesi için koşulların bu ülkelerin koşullarına yakın olması gerekir. Sınıf mevcutlarının ve donanımın Türk eğitim sistemi üzerinde yaptığı baskıyı, bakanlık uzmanlarından çok, uygulayıcıların temsilcisi olan sendika başkanlarının ve öğretim üyelerinin söylemesi dikkate değer başka bir noktadır. Fiziki yapıyla ilgili sorunlar ve öneriler ile programın Amerikan eğitim modellerinden alınması ile ilgili görüşler basına aşağıdaki biçimde yansımıştır:

Sabah gazetesi, 08.09.2005 tarihinde Eğitim-Sen Genel Başkanı Alaaddin Dinçer' in yeni programla ilgili şu görüşlerine yer vermiştir. Alaaddin Dinçer, çalışmaların yeteri kadar değerlendirilmeden tüm illerin bu proje kapsamına alındığı; öğretmen ve öğrencilerin sayfalar dolusu fotokopi çoğaltmak durumunda kalacağı; zaten eğitim harcamalarının giderek el yaktığı bir dönemde, özellikle fotokopiler ve diğer ek materyaller yoluyla yoksul aile çocuklarına çıkarılacak ek masraf dikkate alındığında, bedava kitap uygulamasının nasıl bir yararı kaldığı noktalarına değinmiştir.

15.09.2004 tarihli Cumhuriyet gazetesinde ise, Eğitim-Sen Genel Başkanı Alaaddin Dinçer'in yeni programla ilgili eleştirileri şu şekilde verilmiştir: "Eğitim ve öğretim süreci birbirine karıştırılmış, ütopik bir müfredat, birleştirilmiş sınıflarda öğretmenler bu programı nasıl uygulayacak?, yabancı terminoloji çok fazla kullanılmış, Amerika'nın eğitim modellerinden kopya çekilmiş....Program çok elit bir yaklaşımla hazırlanmış. Niyetten bağımsız. Özel okullar için hazırlanmış bir model gibi..." Dinçer, ayrıca öğretmenlerin bu 
uygulamaya hazır olmadığını, uygulamanın 5 yıllık bir geçiş sürecine yayılması gerektiğini belirtmiştir.

"Eğitim-Sen İzmir 6 Nolu Şube Başkanı Adil Serim, Milli Eğitim Bakanlığı'nı, pilot illerde uygulanmaya başlanan eğitim müfredatını Amerika'dan bire bir tercüme etmekle eleştirdi...Milli Eğitim Bakanlığı'nın Talim Terbiye Başkanlı̆̆ı'nca hazırlanan yeni “Sosyal Müfredatı"nın Amerikan eyaletlerindeki müfredatın bire bir kopyasının olduğu ve kaynak belirtilmeden sözcüklerin aynen tercüme alındığı bildirildi..." Cumhuriyet gazetesi, 16.09.2004.

“...Örneğin, gelecek y1l, mezralar da dâhil her okula internet erişimi sağlanacağı söylendi. Ancak bırakın interneti, bilgisayarı; okullar yakacak kömür, telefonlarını açtıracak kaynak bile bulamıyor. Yeni programa göre, eğitime görsel boyut da kazandırılacakmış. Öğrenciler sınıflarda birlikte film izleyip değerlendirmesini yapacaklarmış. Acaba kaç okulda, kaç sınıfta film gösterici var?..” Abbas Güçlü, Milliyet gazetesi, 13.08.2004.

MEB'e bağlı Eğitimi Araştırma ve Geliştirme Dairesi (EARGED) Başkanlığı'nca yapılan değerlendirme çalışmasının sonuçlarını, 17.06.2005 tarihinde Bahar Atakan Milliyet Gazetesi yazısında sunmuştur. Bu raporda alt yapı ve teknolojik imkânsızlıklarla ilgili olarak şu sonuçlar yer almıştır: Sınıf mevcudunun kalabalık olması, görsel ve teknolojik iletişim araçlarının yetersiz olması. Ayrıca bu rapordan alınan, geri kalmış yörelerle köylerde uygulanan birden fazla sınıfın bir öğretmenin yönetiminde çalışması esasına dayalı sistem olarak bilinen "birleştirilmiş sınıflarda" yeni programın uygulanamayacağı bilgisi de yer almıştır.

05.10.2004 tarihli Sabah gazetesinde bu durum şu şekilde ifade edilmiş: "Araştırma için en önemli kaynak olması beklenen internet ne okullarda ne de öğrencilerin büyük kısmının evinde bulunmuyor. Okullarda ise bilgisayar laboratuarlarından söz etmek çok zor. Bilgisayarlar idarecilerin odalarında, birçoğu da internete bağlı değil. Kent merkezinden beldelere ve köylere gidildiğinde ise "araştırmacı öğrencinin" işi zorlaşıyor."

19.06.2005 tarihli Evrensel gazetesinde Boğaziçi Üniversitesi öğretim üyesi Prof.Dr. Rıfat Okçabol'un görüşlerine yer verilmiş: “...Yeni müfredatın dinlediğim, okuduğum ve izlediğim kadarıyla belki nitelikli okullarda başarı şansı olabilir. Ancak benimsemem mümkün değil. Çünkü bu müfredat anlayışında, öğretmenin askeri talimat gibi kelimesi kelimesine ne söyleyeceğini belirleyip onu bekleyen bir yapısı var...Yeni sistem öğretmeni yetiştirici yerine koyuyor. Sistemin 
iyi olması için de araç gereçlere dayalı eğitim diyor. Ülkedeki 30 bin okuldan kaçında araç gereç var ki!..."

22.06.2005 tarihli Radikal gazetesinde, Sabancı Üniversitesi İstanbul Politikalar Merkezi koordinatörlüğünde yürütülen 'Eğitim Reformu Girişimi' Orta Doğu Teknik, Hacettepe, Sabancı ve Koç üniversitelerinden profesörleri bir araya getirerek yeni programı inceleme sonuçlarına yer vermiştir. Buna göre uzmanlar programda şu eksiklikleri belirlemişlerdir: Programın başarısının araç gereç ve materyal zenginliğine bağlı olması, programın uygulanması için sınıf mevcudunun 25-30'a çekilmesi gerektiği.

Milli Eğitim Bakanlığı İlköğretim Genel Müdürü ise, ilköğretim okullarının fiziksel açıdan yeniden düzenlenmesi konusuyla ilgili görüşlerini ifade etmiştir.

29.01.2005 tarihli Tercüman gazetesinde Milli Eğitim Bakanlı̆̆ İlköğretim Genel Müdürü Prof.Dr. Servet Özdemir'in görüşlerine yer verilmiştir. Özdemir, yeniden yapılanma programı çerçevesinde büyük çoğunluğu gri renkte olan ilköğretim okullarının çeşitli renklerle boyanacağını; okulların öğretmeni, öğrencisi ve velisiyle bir sosyal merkez haline geleceğini; yeni okulların mimarilerinin Selçuklu ve Osmanlı tarzında olacağını belirtmiştir.

Basında yer alan bir diğer araştırma ise, Eğitim-Sen tarafından gerçekleştirilen araştırma olmuştur.

05.08.2005 tarihli Evrensel gazetesinde, Eğitim-Sen'in araştırma sonucunda yeni ilköğretim programıyla ulaştığı önerilere yer verilmiştir: "Müfredatta bilgi ve değerler gerçekçi olmalı, sınav ve not sistemi üzerine kurulmamalı; bireysel ve bölgesel farklılıklar dikkate alınmalı; etkinlikler öğrenci merkezli olmalı; birinci sınıfta bilmece ve tekerlemeler konulmalı; program ekonomik yönden mutlaka desteklenmeli; matematik dersliği, fen dersliği gibi derslikler oluşturulmalı; çeşitli konularda öğrenci-veli anketleri düzenlenmeli; sınıf mevcutları 30 kişinin altına çekilmeli; pilot okullarda çalışan öğretmenlerin uzmanlığından yararlanılmalı"

\section{Ölçme -Değerlendirme}

Türk Eğitim sisteminin en önemli sorunlarından birisi de ölçme ve değerlendirme sorunudur. Yeni programlarda kullanılan ölçme değerlendirme anlayışının ve yöntemlerinin tam olarak anlaşılamadığı ya da 
uygulama evresinde olduğu için sorunların basına yansımadığı görülmüştür. İncelenen haberler içinde yalnızca bir haberde, öğretmen görüşlerine dayalı olarak ölçme değerlendirme konusunun sorun olduğu belirtilmiştir. Standart sınavların belirleyici olduğu ve toplumdaki herkesin bunların sonucuna dayalı olarak eğitimin niteliği konusunda değerlendirmeye gittiği eğitim sisteminde, sonuçtan çok sürece dayalı bir değerlendirme anlayışı, ne öğretmenler ne de velilerce pek kabul görmemiştir. Programa ilişkin tanıtım çalışmalarında, aileler en çok Orta Öğretim Kurumları Giriş Sınavı (OKS) ne olacak, daha ilerisinde neler olacak gibi soruları sormuşlardır. Programın ölçme değerlendirme boyutu konusunda basına yansıyan görüşleri aşağıdaki biçimde özetlemek mümkündür:

Programın ölçme-değerlendirme boyutuyla ilgili olarak, diğer boyutları kadar olmasa bile, görüşlere ve araştırmalara yer verilmiştir.

“...Ölçme ve değerlendirme yöntem ve teknikleri yetersiz..." Bahar Atakan, Milliyet gazetesi, 17.06.2005.

“...Ölçme değerlendirme anlayışında sadece sonuç değil, gidiş süreci de önemsendi..”(Milli Eğitim Bakanı Hüseyin Çelik) Cumhuriyet gazetesi, 12.08.2004.

“...Yeni müfredat programını uygulama sürecinde öğretmenlerin en çok zorlandıkları konu ise Ölçme ve Değerlendirme Teknikleri oldu. Yeni teknikler öğretmenlerin yüzde 72'si tarafından karmaşık, yüzde 95'ince de "zaman alıcı" bulundu." Ali Sali, Yeni Şafak gazetesi, 04.09.2005.

Basına yansıyan en ilginç haberlerden birisi de Türk eğitim sistemine ilişkin ülkede görev yapan yabancı uzmanların da görüş bildirmesi olmuştur. Dünyada hiçbir eğitim sistemi Türk eğitim sistemi gibi kuşatılmış değildir. Yeni programların hazırlanmasında yabancı uzmanlardan yararlanılmış olmasına karşılık bazılarının bunu yeterli görmemesi, Osmanlı Devleti'nin son dönemlerinde milletlerin İstanbul'da okul kurarken birbirlerini eleştirmelerine benzemektedir. Basına yansıyan bu ilginç görüş aşağıdaki gibidir:

Sabah gazetesi TED İstanbul Koleji AB Eğitim Programları Danışmanı Paddy Carpenter'ın görüşlerine yer vermiş. Carpenter "Müfredat değişikliği teknik değişimlerle olmaz. Davranışlarla, bakış açısıyla ve açıklıkla olur... Sadece İngilizce değil Fransızca'ya da önem verilmeli çünkü AB'de Fransızca konuşuluyor. Bunun dışında diğer ülkelerin tarihine ağırlık verilmeli" önerilerinde bulunmuştur. 
Bunların dışında, yeni ilköğretim programının bazı teknik özellikleri ile ilgili bilgilendirme amaçlı yazılar da basında yerini bulmuştur.

“...İlköğretim 1. sınıfta hece yönteminden "ses temelli cümle yöntemi”ne geçilecek. İlköğretim öğrencileri daha önceki müfredatın aksine "rahatlatılmış" bir ders çizelgesiyle eğitim görecekler. Bu anlamda spordan dramaya kadar pek çok seçmeli ders öğrencilere seçenek olarak sunulacak. Düzenleme kapsamında, eskiden 3 saat işlenen Fen Bilgisi dersi, "Fen ve Teknoloji" dersi adı altında haftada 4 saat işlenecek. Eski çizelgede yer alan Vatandaşlık ve İnsan Hakları Eğitimi dersi ise kaldırılırken, bu konu Hayat Bilgisi, T.C. İnkılâp Tarihi ve Atatürkçülük gibi derslerin içinde işlenecek..." Vatan gazetesi, 11.09.2005.

“...Hayat Bilgisi dersinde çocuk, doğayı, toplumu, kendisini tanıyarak yaşama hazırlanacak. Hata yapmaktan ve kaybetmekten korkmamay1, suçluluk duymadan nasıl hayır diyeceğini öğrenecek. 3. sınıfta organlar ve işlevleri ezbere değil, "vücut şirketi” etkinliğiyle öğrenilecek. Öğrenci işçi çıkarmak zorunda kalan şirketin çalışanı olacak, bir organı canlandıracak..." Nilüfer Kas, Tempo dergisi, 05.10.2004.

“...Sosyal Bilgiler dersindeyse davranışçı anlayış yerine oluşturmacı anlayış ön planda, Önceden bilgiyi sunma, talimatlara uyma ve geri bildirim önemliyken, yeni sistem düşünme becerilerini ön plana çıkararak bilgiye ulaşmayı ve öğrenmeyi önemsiyor. Ayrıca öğrenciyi ölçme ve değerlendirme konusu da yeni sistemde unutulmamış." Perihan Özcan Tüzüner, Yeni Aktüel dergisi, 26.09.2005.

\section{SONUÇ}

Türk eğitim sistemi yıllardır farklı reform çabalarıyla karşı karşıya kalmıştır. Özellikle 1980 sonrasında bu reform çabalarının basın aracılığı ile kamuoyuna tanıtılması bir gelenek haline gelmiştir. 1991 yılında Milli Eğitim Bakanı'nın televizyondan yaptığı açıklamayla liselerde kredi ve ders geçme sisteminin uygulaması başlatılmış, alt yap1 ve öğretmen bilgilendirilmesi eksikliği nedeniyle yaşanan sorunlar bu düzenlemeye fatura edilmiştir. Sonuçta, Başbakan'ın yine televizyondan yaptığı bir açıklamayla uygulamadan kaldırılmıştır. Basın aslında önemli bir görevi yerine getirmiştir. $\mathrm{Bu}$ görevi yerine getirirken dikkat edilmesi gereken birçok noktayı da kendi söylemleri ya da bakış açılarıyla vermiştir. Bu çalışma sonucunda basının programın halka tanıtılmasında görevini yeterince yerine getirdiğini söyleyebiliriz; ama yalnızca tanıtma ve bilgilendirme konusunda. 
Oysa ki, basın yalnızca tanıtma ve bilgilendirme görevini üstlenmemeli, aynı zamanda reform çabalarına yön verici olmalıdır.

Batıdaki birçok basın organı, sosyo-ekonomik ve kültürel alandaki yeniliklerin ülkeye getirdikleri ve götürdükleri konusunda kamuoyunu bilgilendirmekte, deyim yerindeyse, yönlendirmektedir. $\mathrm{Bu}$ eleştiriler oldukça dikkate alınmakta ve değişim bazen bu eleştiriler çerçevesinde belli bir yöne girmektedir. Türkiye'de ise, birkaç önemli görüş dıșında, basın yalnızca görüşleri aktarma görevini üstlenmiştir. Programın teknik boyutunun tartışıldığı, kavramların çözümlendiği yazılara ise pek yer verilmediği ortaya çımaktadır. Basın da, geleneksel neoliberal ve muhafazakâr söylemi haberlerine yansıtmıştır. Kamuoyunu bilinçlendirirken belli bir başarı yakalanmış, konu, yüzden fazla haber organında haberlere yansımıştır.

Basında yapılan haber, görüşme ve köşe yazılarının özetlendiği bu çalışmada, basının, programların felsefesini, programın uygulanmasındaki sorunları ve önerileri belli başlıklar altında ele aldığı ortaya çıkmıştır. Bu görüşlerin daha sonraki dönemlerde daha iyiyi getirme konusunda yararlı olduğu kabul edilmekle birlikte, daha sonra bu konuların izlenmemesi ve sonuçların değerlendirilmemesi basının yalnızca haberci olarak kalmasına yol açmıştır (Giddens, 2005). Burada basının çoğunlukla kamuoyunu haberdar etme işlevini yerine getirdiği söylenebilir. Programın uygulanmasından sonra geçen dönemde neler yapıldığının izlenmemesi soru işaretlerine yol açmıştır. Türkiye'de belki de en önemli sorunlardan birisi budur, yani, sürecin izlenmemesi ve sonuçlandırılmaması ya da zamana bırakılmasıdır. $\mathrm{Bu}$ konuda en ısrarlı yazıların bazı gazetelerin köşe yazarlarınca yazılmış olması belki de basın adına söylenecek en önemli katkılardan birisidir. Bütün bunların ötesinde yine de basının görevini yerine getirmede önceki dönemlere göre daha başarılı olduğunu kabul etmek gerekir. Çünkü araştırmacıların hizmetiçi eğitim programlarında öğretmenlerle yaptıkları görüşmelerde, öğretmenlerin birçoğu konuyu basından izlediklerini belirtmişlerdir. Birçok bilim adamı da basından aldığı bilgiye dayalı olarak araştırma düzenekleri oluşturmuşlardır. Bu çalışma da basının katkılarını belli ölçüde ortaya çıkarabilmiştir. 


\section{KAYNAKLAR}

Aktaş, U. (18.02.2005). Ezber yok, tartışma var. Radikal Gazetesi.

Akyüz, Y. (2006). Türk eğitim tarihi (dokuzuncu baskl). İstanbul: Alfa Yayınları.

Atakan, B. (17.06.2005). Yeni müfredat zayıf. Milliyet Gazetesi.

Atılgan, Z. (12.08.2004). Türk eğitimine AB'li bakış. Sabah Gazetesi.

Babahan, E. (10.08.2004). Milli Eğitim'e yeni düzen. Sabah Gazetesi.

Benmayor, G. (13.08.2004) Eğitim reformunu dikkatle izleyelim. Hürriyet Gazetesi.

Çakmak, O. (19.08.2004). Gelin buna (kuantum eğitimi) reform diyelim!. Zaman Gazetesi.

Çakmakçı, N. (05.09.2004). İşte 64 yıllık ilköğretimi değiştiren ekip. Hürriyet Gazetesi.

Demirel, Ö. (2004). Kuramdan uygulamaya: ě̆itimde program geliştirme (yedinci baskı). Ankara: PegemA Yayıncilı.

Derviş, A. (11.09.2004). Yeni sosyal bilgiler programı kimin?. Evrensel Gazetesi.

Durbaş, R.. (30.08.2004). Malzeme tamam, ya aşçılar?. Sabah Gazetesi.

Dündar, C. (14.08.2004). "Hayır" diyebilen çocuklar. Milliyet Gazetesi.

Eğitim geriye doğru gitti. (15.09.2005). Cumhuriyet Gazetesi.

Eğitimde akla hayır dönemi. (19.06.2005). Evrensel Gazetesi.

Eğitim-Sen'in önerileri. (05.08.2005). Evrensel Gazetesi.

Etyemez, H. (29.08.2005). Müfredat değişimi eğitimi nasıl etkiler?. Yeni Şafak Gazetesi.

Ertürk, S. (1985). Eğitimde program geliştirme, Ankara: Hacettepe Üniversitesi Basımevi.

Gedik, D. (11.09.2005). 14 milyon öğrenci "sıfır kilometre" eğitimle yola çıkıyor. Vatan Gazetesi.

Giddens, A. (2005). Sociology (5 $5^{\text {th }}$ ed.). London: Polity.

Gözütok, F. D. (2005). Özensiz, altyapısı yetersiz bir program. Öğretmen Dünyası Dergisi, 7-8, 298.

Gözütok, F. D., Karacaoğlu, C., Akgün, Ö. (2005). İlköğretim programlarının öğretmen yeterlikleri açısından değerlendirilmesi. 
Eğitimde Yansımalar: VIII, Yeni İlköğretim Programlarını Değerlendirme Sempozyumu, 14-16 kasım 2005. 16-38., Kayseri.

Güçlü, A. (12.07.2005). Okuma yazmada yeni yöntem. Milliyet Gazetesi.

Güçlü, A. (16.09.2004). İyi birey, iyi insan ve vatandaş yetişecek. Milliyet Gazetesi.

Güçlü, A. (13.08.2004). Yeni müfredat programı. Milliyet Gazetesi.

Gündem. (08.09.2005). İlköğretim öğrencilerinin kitap dağıtımı tamamlandı: "yeni kitaplar daha sevecen". Hürriyet Gazetesi.

Gündem. (08.09.2005). Eğitim-Sen: yeni müfredat ekmasraf doğuracak. Sabah Gazetesi.

Gündem. (05.10.2004). Artık öğrenci ders anlatıyor. Sabah Gazetesi.

Gündem, M. (15.08.2004). Çocuğa demokrasi kültürü aşılanacak. Milliyet Gazetesi.

Güngör, D. (17.07.2004). Eğitim devrimi beş referanslı. Radikal Gazetesi.

Güngör, D. (11.08.2004). En şenlikli müfredat. Radikal Gazetesi.

Güngör, D. (17.08.2004). Her sınıfta bi hükümet olacak. Radikal Gazetesi.

Güven, İ. (2000). Türkiye'de devlet-eğitim ve ideoloji. Ankara: Siyasal Kitapevi.

Hızlandırılmış müfredat faciası sınıflarda. (15.09.2004). Cumhuriyet Gazetesi.

EPÖ Profesörler Kurulu Yeni İlköğretim Programını Değerlendirme Toplantıs1, Sonuç Bildirisi. 10.7.2006 tarihinde http://ilkogretimonline.org.tr/vol5say1/sbildirge alınd1.

İlköğretim müfredatı açıklandı. (11.08.2004). Hürriyet Gazetesi.

İlköğretim müfredat programı açıklandı. (13.6.2006). Hürriyet Gazetesi.

İlköğretim tepeden tırnağa değişecek. 29.01.2005, Tercüman Gazetesi.

İlköğretime yeni program. 12.08.2004, Cumhuriyet Gazetesi.

İşman, Z. Ezbercilik tarih oluyor. 12.08.2004, Sabah Gazetesi.

Kaplan, P. Mecburi gönüllü. 09.08.2004, Sabah Gazetesi.

Kas, N. Yeni müfredat manzaraları. 05.10.2004, Tempo Dergisi.

Kavakl1, E. A. Eğitimde reform. 02.09.2005, Vakit Gazetesi.

Kızıltepe, Z. Okullardaki kısırdöngü. 13.06.2005, Radikal Gazetesi. 
Laik ögretim vurgusu. 12.09.2005, Cumhuriyet Gazetesi.

Müfredat tercüme eseri. 16.09.2004, Cumhuriyet Gazetesi.

Okuma-yazma önce harf ögrrenme ile başlayacak. 26.08.2005, Yeni Şafak Gazetesi.

Ornstein, A. C. and Hunkins, F.P. (1998). Curriculum: foundations, principles and issues(third edition). United States of America: Allyn and Bacon.

Sali, A. Yeni müfredata tam not. 04.09.2005, Yeni Şafak Gazetesi.

Şafak, E. Milli Eğitim'i alkışlıyoruz. 11.09.2005, Sabah Gazetesi.

Sowell, E.J. (2005). Curriculum: an integrative introduction ( $3^{\text {rd }}$ ed.). New Jersey: Merill Prentice Hall.

Tüzüner, P. Ö. 26.09.2005, Yeni Aktüel Dergisi

Ün, M. Eğitimin ezberi bozuluyor. 11.08.2004, Zaman Gazetesi.

Yeni müfredat sınıfı geçti. 22.06.2005, Radikal Gazetesi. 